\title{
Renal colic and childbirth pain: female experience versus male perception
}

\author{
This article was published in the following Dove Press journal: \\ Journal of Pain Research \\ 5 July 2017 \\ Number of times this article has been viewed
}

\author{
Saiful Miah ${ }^{1,2}$ \\ Charlotte Gunner ${ }^{3}$ \\ Lucy Clayton ${ }^{4}$ \\ Suresh Venugopal ${ }^{5}$ \\ Nigel R Boucher ${ }^{5}$ \\ Bo Parys ${ }^{6}$ \\ 'Division of Surgery and \\ Interventional Science, University \\ College London, London, UK; \\ 2Urology Department, Charing \\ Cross Hospital, Imperial College \\ Healthcare NHS Trust, London, \\ UK; ${ }^{3}$ Urology Department, \\ Raigmore Hospital, Inverness, UK; \\ ${ }^{4}$ Psychiatry Department, Highbury \\ Hospital, Nottingham, UK; ${ }^{5}$ Urology \\ Department, Chesterfield Royal \\ Infirmary, Chesterfield, UK; ${ }^{6}$ Urology \\ Department, Rotherham General \\ Hospital, Rotherham, UK
}

\section{Introduction}

Renal colic is often described by patients as the worst pain ever experienced. ${ }^{1}$ Pain during childbirth is also similarly described. ${ }^{2}$ To date, no study has comparatively evaluated the pain of renal colic to that of childbirth in female patients who have experienced both. Furthermore, no such study has evaluated the perception that men with renal colic have with respect to the pain experienced during childbirth. Here we present our cross-sectional observational study to address these questions. The primary objectives of our study were to answer these questions and highlight the severity of renal colic which is not always faced and treated aggressively.

\section{Materials and methods}

Fifty-nine patients across two centers (Rotherham General Hospital, UK and Chesterfield Royal Hospital, UK) were asked to complete a visual analog scale questionnaire to assess the severity of their renal colic (minimum: 1, maximum: 10). All patients had confirmed ureteric stones on $\mathrm{CT}$ imaging and were asked if their renal colic was the most painful condition they have ever suffered. All primiparas and multiparas females were asked if their renal colic was more painful than childbirth. All men were asked to provide an opinion on what they imagined would be more painful - their renal colic or the pain associated with childbirth.

The study gained ethical approval from Chesterfield Royal Hospital Research and Ethics Department. All patients provided written consent to in order to participate in the study.

\section{Results}

Thirty-six male and 23 female patients fully completed the questionnaire with age, stone size, and numerical pain rating score recorded (Table 1). There were no statistically significant differences in these parameters between male and female patients $(p>0.05$, Student's $t$-test). From the male cohort of patients, $88.9 \%(n=32)$ stated that it was the worst pain they had ever experienced and for the female cohort this was $78.2 \%(n=19)$.

From the female cohort of patients, 19 had given birth previously with $63.3 \%(\mathrm{n}=12)$ saying that renal colic was more painful and a further $15.7 \%(n=3)$ felt that the intensity of pain was similar. Twenty-one percent of $(n=4)$ female patients who had experienced both childbirth and renal colic stated that childbirth was a more painful experience.
Correspondence: Saiful Miah

Division of Surgery and Interventional Science, 4th Floor, University College London Medical School Building, 2I University Street, London WCIE 6AU, UK

Tel +442076799060

Email saiful.miah@ucl.ac.uk 
Table I Results from the visual analog scale questionnaire

\begin{tabular}{llllllll}
\hline & $\begin{array}{l}\text { Mean age } \\
\text { (years) }\end{array}$ & $\begin{array}{l}\text { Mean size of } \\
\text { stone }(\mathbf{m m})\end{array}$ & $\begin{array}{l}\text { Mean numerical pain } \\
\text { rating (min: I, max: 10) }\end{array}$ & $\begin{array}{l}\text { Renal colic - } \\
\text { most severe pain } \\
\text { experienced }\end{array}$ & \multicolumn{2}{l}{$\begin{array}{l}\text { Pain experienced/opinion of } \\
\text { renal colic versus childbirth* }\end{array}$} \\
\cline { 5 - 9 } & & & 9.8 & $78.2 \%$ & More & Same & Less \\
\hline Female $(n=23)$ & 47.6 & 5.1 & 9.4 & $88.9 \%$ & $3.3 \%$ & $15.7 \%$ & $21 \%$ \\
Male $(n=36)$ & 50.3 & 5.8 & $36.6 \%$ & $23.4 \%$ & $40 \%$ \\
\hline
\end{tabular}

Notes: *For females, from 19 patients who have experienced both renal colic and childbirth.

In contrast, the majority of male patients imagined that the pain from their renal colic was less painful $(40 \%)$ or comparable (23.4\%) to that of childbirth.

\section{Discussion}

The results of our study suggest that renal colic was the worst pain for the majority of female patients who have experienced both forms of pain. In contrast, $63.4 \%$ of men imagined that the pain of childbirth is worse or as severe as that from their renal colic.

Renal colic should be managed by a swift stepwise and progressive analgesia regime. Pain associated with childbirth is well recognized and follows involvement of the pain team or anesthetist in pain control during labor. In contrast, renal colic pain is managed generally in the acute setting by either emergency care practitioners or the urologist. Optimal pain management in renal colic patients in the shortest possible time is vital as this group can on occasion be left with inadequate analgesia for lack of understanding of the intensity pain. ${ }^{3}$

Our study has several limitations. They include limitations in numbers with only 19 women who experienced both renal colic and childbirth. We assessed labor pain retrospectively which will include an element of recall bias. Further work could potentially include assessing female patients in their acute pain phase of labor and who have experienced renal colic pain prior to childbirth.

To conclude, our study underlines and highlights the urgency and importance required when administering effective analgesia for female and male patients presenting with renal colic as that would be expected from those experiencing childbirth.

\section{Disclosure}

The authors report no conflicts of interest in this work.

\section{References}

1. Golzari SE, Soleimanpour H, Rahmani F, et al. Therapeutic approaches for renal colic in the emergency department: a review article. Anesth Pain Med. 2014; 4(1):e16222.

2. Yerby M. Pain relief: past and present. In: Pain in childbearing: key issues in management. 6th ed. London: Elsevier Health Sciences; 2000;5.

3. Behzadnia MJ, Javadzadeh HR, Saboori F. Time of admission, gender and age: challenging factors in emergency renal colic - a preliminary study. Trauma Mon. 2012;17(3):329-332.

\section{Publish your work in this journal}

The Journal of Pain Research is an international, peer reviewed, open access, online journal that welcomes laboratory and clinical findings in the fields of pain research and the prevention and management of pain. Original research, reviews, symposium reports, hypothesis formation and commentaries are all considered for publication.

\section{Dovepress}

The manuscript management system is completely online and includes a very quick and fair peer-review system, which is all easy to use. Visit http://www.dovepress.com/testimonials.php to read real quotes from published authors. 